Rochayat, Y • A. C. Amalia $\cdot$ A. Nuraini

\title{
Pengaruh pemangkasan terhadap pertumbuhan: Percabangan dan pembesaran bonggol tiga kultivar Kamboja Jepang (Adenium arabicum)
}

\section{Effect of pruning on growth: Branching and stump enlargement three cultivars of "Kamboja Jepang" (Adenium arabicum)}

Diterima : 17 Agustus 2017/Disetujui : 25 Agustus 2017 / Dipublikasikan : 31 Agustus 2017

CDepartment of Crop Science, Padjadjaran University

\begin{abstract}
Adenium arabicum has sales and high aesthetic value as the requirements of ornamental plants. The beauty of the exotic stump and lot of branch are the important characteristic and could as character to distinguish Adenium species. However, to get a lot of branching and stump enlargement requiring time in A. aracium, one of the efforts to speed up the desired form is by pruning. This research aimed to determine the effect of pruning on growth (branching and stump enlargement) of three cultivars of A. arabicum. Experiment was carried out on April until June 2016 at Ciparanje Experimental Station, Faculty of Agriculture, Padjadjaran University, Jatinangor, Sumedang, West Java. Experiment was arranged in Randomized Block Design of two factors. The first factors is a cultivars (K) consist of 3 levels (Yak Saudi, RCN, and Thai Socotranum) and the second factors is type of pruning $(\mathrm{P})$ consisted of 3 levels (without pruning, pruning 7 segments, and pruning 14 segments) with three replications. The result of the experiment showed that there was interaction between three cultivars and branching in increasing the diameter of the stump A. arabicum at 6 weeks after pruning. This effect was showed in the treatment Yak Saudi cultivars with without pruning showed. There was no different among three cultivars on all parameters. However, the pruning 14 segments showed the best effect in increasing the number of branches, branch length, number of leaves and leaf area on the plant of $\mathrm{A}$. arabicum
\end{abstract}

Keywords : Adenium arabicum • Pruning $\cdot \mathrm{RCN}$. Thai socotranum $\cdot$ Yak Saudi

\footnotetext{
Dikomunikasikan oleh Erni Suminar

Rochayat, $\mathrm{Y}^{1} \cdot$ A. C. Amalia ${ }^{2} \cdot$ A. Nuraini ${ }^{2}$

Program Studi Agroteknologi, Fakultas Pertanian,

Universitas Padjadjaran

Korespondensi: amali4dinda@yahoo.com
}

Sari Tanaman hias Adenium arabicum memiliki nilai jual dan estetika yang tinggi. Keindahan akan bonggol yang eksotik dan percabangan yang banyak merupakan ciri khas yang membedakan dengan spesies Adenium lainnya. Akan tetapi, untuk mendapatkan percabangan yang banyak dan bonggol yang eksotik memerlukan waktu yang cukup lama, sehingga perlu dilakukan upaya untuk mempercepat bentuk A. arabicum yang diinginkan, yaitu dengan pemangkasan. Tujuan dari penelitian ini, yaitu untuk mengetahui pengaruh pemangkasan terhadap pertumbuhan, yaitu percabangan, dan pembesaran bonggol tiga kultivar A. arabicum. Percobaan dilaksanakan pada bulan April hingga Juni 2016 di Kebun Percobaan Ciparanje, Fakultas Pertanian, Universitas Padjadjaran, Jatinangor, Sumedang, Jawa Barat. Percobaan menggunakan Rancangan Acak Kelompok (RAK) Pola Faktorial dengan dua faktor. Faktor pertama, yaitu kultivar $(\mathrm{K})$ terdiri atas 3 level (Yak Saudi, RCN, dan Thai Socotranum) dan faktor kedua, yaitu pemangkasan terdiri atas 3 level (tanpa pemangkasan, pemangkasan ruas ke-7 dan ruas ke-14) dengan tiga ulangan. Hasil penelitian menunjukkan bahwa terdapat interaksi antara perlakuan pemangkasan dan tiga kultivar terhadap pertambahan diameter bonggol tanaman $A$. arabicum pada umur 6 MSP. Interaksi yang terjadi, yaitu antara kultivar Yak Saudi dengan tanpa pemangkasan. Perlakuan pada tiga kultivar tidak memberikan pengaruh yang berbeda. Pemangkasan pada ruas ke-14 memberikan pengaruh paling baik terhadap pertambahan jumlah cabang, panjang cabang, jumlah daun, dan luas daun pada tanaman A. arabicum.

Kata kunci : Adenium arabicum - Pemangkasan • RCN, Thai socotranum $\cdot$ Yak Saudi. 


\section{Pendahuluan}

Tanaman hias merupakan tanaman yang memiliki nilai estetika yang tinggi dan dapat memberikan rasa nyaman bila diletakkan di dalam ruangan. Suryowinoto 1997 menyatakan, bahwa penggemar tanaman hias semakin meningkat sejalan dengan meningkatnya status sosial, ilmu pengetahuan dan teknologi. Tanaman hias yang banyak terdapat di lingkungan rumah tinggal, perkantoran maupun di lingkungan taman-taman rekreasi dapat memberikan pengaruh positif terhadap kehidupan manusia, menciptakan suasana segar, nyaman, dan harmonis. Salah satu tanaman hias yang memiliki nilai estetika dan ekonomi tinggi, yaitu tanaman hias Adenium.

Tanaman Adenium dikenal luas di seluruh dunia dan hingga kini menjadi salah satu tanaman hias yang popular di Asia. Beberapa negara di Asia, seperti Taiwan, Thailand, dan India menjadi sentra agrobisnis yang telah banyak mengembangkan tanaman Adenium (Arwida, 2008). Tanaman Adenium ini telah ada sejak tahun 2000-an yang dikenal dengan sebutan Kamboja Jepang. Semakin berkembangnya zaman, tanaman Adenium mulai diminati oleh banyak masyarakat Indonesia dengan dikenalkannya berbagai variasi bunga hasil persilangan spesies Adenium obesum. Selain spesies $A$. obesum yang banyak diminati, tanaman Adenium dengan spesies lain pun mulai berkembang pesat, seperti Adenium arabicum. Tanaman $A$. arabicum ini memiliki keindahan tersendiri bagi orang yang melihat-nya. Keindahan yang ditampakkan dari tanaman $A$. arabicum ini selain dari bunganya, keindahan akan bonggolnya yang eksotik dan memiliki jumlah percabangan yang banyak adalah ciri khas yang membedakan spesies Adenium ini dengan spesies lainnya (Arwida, 2008).

Keindahan yang dimiliki tanaman $A$. arabicum merupakan ciri khas dari spesies $A$. arabicum juga menjadi faktor penentu terhadap nilai jualnya, sehingga perlu dilakukan upaya untuk mempercantik tampilan dari $A$. arabicum. Salah satu upaya mempercantik tampilan $A$. arabicum, yaitu dengan perlakuan pemangkasan. Menurut Januwati dkk. (1996), pemangkasan merupakan cara mengatur dominasi apikal agar dapat ditiadakan, yang selanjutnya akan merangsang pada pembentukan cabang-cabang baru. Pemangkasan yang dapat dilakukan yaitu pemangkasan batang utama atau pemangkasan cabang. Pemangkasan pada bagian atas tanaman mengakibatkan hilangnya dominansi apikal dan menstimulasi tumbuhnya tunas-tunas baru pada bagian aksiler batang. Dominansi apikal adalah pengaturan pertumbuhan dominansi ujung tanaman yang menekan daerah merisematik lainnya. Dominansi apikal ini memiliki peran dalam percabangan pada tanaman $A$. arabicum Dwijoseputro (1992).

Pemangkasan juga dapat berpotensi untuk memperbesar bonggol dari A. arabicum. Upaya menghilangkan bagian atas tanaman dapat membantu translokasi asimilat yang ada pada meristem apikal ke bagian bawah tanaman, yaitu ubi (Ali, 1996). Ubi pada tanaman A. arabicum dapat disebut dengan bonggol. Bonggol ini merupakan akar bagian atas yang membesar yang dapat menyimpan cadangan makanan bagi tanaman A. arabicum (Soenanto, 2005). Pemangkasan juga dapat memperbaiki pencahayaan dari sinar matahari ke seluruh bagian tanaman agar proses fotosintesis dapat berlangsung sempurna dan dapat mengurangi kelembaban sehingga tanaman terhindar dari serangan hama dan penyakit (Irawati dan Setiari, 2006).

Tanaman A. arabicum memiliki potensi untuk dijadikan sebagai tanaman yang memiliki nilai jual tinggi dengan keindahan tajuk tanaman dan bonggol yang eksotik. Keterbatasan dari tanaman ini adalah jumlah cabang yang sedikit dan diameter bonggol yang relatif kecil ketika tanaman masih berumur muda, yang merupakan salah satu daya tarik dari tanaman A. arabicum. Hasil penelitian ini diharapkan dapat memberikan solusi mengenai keterbatasan dari tanaman $A$. arabicum dengan mengetahui pengaruh pemangkasan terhadap pertumbuhan, percabangan dan pembesaran bonggol tiga kultivar A. arabicum.

\section{Bahan dan Metode}

Percobaan dilakukan di rumah kaca Kebun Percobaan Ciparanje, Fakultas Pertanian, Universitas Padjadjaran, Jatinangor, Sumedang, yang memiliki ketinggian tempat 730 meter di atas permukaan laut $(\mathrm{m} \mathrm{dpl})$. Waktu percobaan dilaksanakan dari bulan Maret 2016 sampai dengan bulan Mei 2016.

Bahan yang digunakan, antara lain: tiga kultivar tanaman A. arabicum, yaitu Yak Saudi, $\mathrm{RCN}$, dan Thai Socotranum yang telah berumur 
satu tahun dengan 8-15 helai daun; media tanam berupa campuran pasir malang, arang sekam, dan kompos; arang kayu; serta polybag berukuran $25 \times 25 \mathrm{~cm}$ berwarna hitam sebagai tempat media tanam. Alat yang digunakan antara lain: gunting pangkas, cutter, jangka sorong, leaf area meter, termohygrometer, lux meter, kertas label, handsprayer, kamera, serta alat tulis.

Rancangan percobaan yang digunakan adalah Rancangan Acak Kelompok (RAK) dengan pola faktorial. Faktor pertama adalah kultivar $A$. arabicum $(\mathrm{K})$, yang terdiri atas tiga taraf perlakuan $\left(\mathrm{k}_{1}=\right.$ kultivar Yak Saudi, $\mathrm{k}_{2}=$ kultivar RCN, $\mathrm{k}_{3}=$ kultivar Thai Socotranum) dan faktor kedua adalah pemangkasan $(\mathrm{P})$, yang terdiri atas dua taraf perlakuan $\left(\mathrm{p}_{0}=\right.$ tanpa pemangkasan, $\mathrm{p}_{1}=$ pemangkasan pada ruaske-7, $\mathrm{p}_{2}=$ pemangkasan pada ruas ke-14). Setiap perlakuan diulangi sebanyak tiga kali. Pemangkasan dilakukan pada awal percobaan saat tanaman berumur 13 bulan. Data dianalisis dengan menggunakan analitis ragam dan jika terdapat pengaruh nyata dilanjutkan dengan Uji jarak Berganda Duncan Multiple Range Test (DMRT) pada taraf nyata 5\% (Gomez dan Gomez, 1995).

\section{Hasil dan Pembahasan}

Pertambahan Jumlah Cabang. Berdasarkan hasil analisis statistik tidak terjadi interaksi antara perlakuan kultivar dengan pemangkasan terhadap pertambahan jumlah cabang dari tanaman A. Arabicum. Pengaruh mandiri perlakuan pada tiga kultivar dan pemangkasan terhadap pertambahan jumlah cabang dapat dilihat pada Tabel 1.

Tabel 1. Pengaruh Pemangkasan pada Tiga Kultivar terhadap Pertambahan Jumlah Cabang Tanaman Kamboja Jepang (A. arabicum).

\begin{tabular}{ccccccc}
\hline \hline \multirow{2}{*}{$\begin{array}{c}\text { Perla- } \\
\text { kuan }\end{array}$} & \multicolumn{5}{c}{ Pertambahan Jumlah Cabang } \\
\cline { 2 - 7 } $\mathrm{k}_{1}$ & 2 MSP & 4 MSP & 6 MSP & M MSP & $10 \mathrm{MSP}$ & $12 \mathrm{MSP}$ \\
$\mathrm{k}_{2}$ & $0,11 \mathrm{a}$ & $1,33 \mathrm{a}$ & $0,22 \mathrm{a}$ & $0,00 \mathrm{a}$ & $0,00 \mathrm{a}$ & $0,00 \mathrm{a}$ \\
$\mathrm{k}_{3}$ & $0,11 \mathrm{a}$ & $1,05 \mathrm{a}$ & $0,22 \mathrm{a}$ & $0,00 \mathrm{a}$ & $0,00 \mathrm{a}$ & $0,00 \mathrm{a}$ \\
\hline $\mathrm{p}_{0}$ & $0,00 \mathrm{a}$ & $0,00 \mathrm{a}$ & $0,00 \mathrm{a}$ & $0,00 \mathrm{a}$ & $0,00 \mathrm{a}$ & $0,00 \mathrm{a}$ \\
$\mathrm{p}_{1}$ & $0,11 \mathrm{a}$ & $1,50 \mathrm{~b}$ & $0,27 \mathrm{~b}$ & $0,00 \mathrm{a}$ & $0,00 \mathrm{a}$ & $0,00 \mathrm{a}$ \\
$\mathrm{p}_{2}$ & $0,22 \mathrm{a}$ & $2,05 \mathrm{c}$ & $0,38 \mathrm{~b}$ & $0,00 \mathrm{a}$ & $0,00 \mathrm{a}$ & $0,00 \mathrm{a}$ \\
\hline \hline
\end{tabular}

Keterangan: Angka yang ditandai dengan huruf berbeda menyatakan berbeda nyata menurut Uji Lanjut Berganda Duncan pada taraf 5\%.

Perlakuan pada tiga kultivar tidak memberikan perbedaan yang nyata terhadap pertambahan jumlah cabang A. arabicum. Hal tersebut karena karakteristik pertumbuhan dari ketiga kultivar cenderung lambat. Menurut Arwida (2008), kultivar Yak Saudi dan Thai Socotranum memiliki karakteristik pertumbuhan yang lambat. Karakteristik pertumbuhan yang lambat ini menjadikan tanaman yang diujikan belum memberikan perbedaan yang nyata hingga umur tanaman 12 MSP.

Perlakuan pemangkasan menunjukkan pertambahan jumlah cabang setiap minggunya hanya hingga umur 6 MSP dan cenderung tidak mengalami pertambahan lagi pada umur 8 MSP dan seterusnya. Hal tersebut diduga akibat dilakukannya pemangkasan, translokasi fotosintat lebih terfokus pada pembesaran bonggol, sehingga belum terlihat pengaruhnya terhadap pembentukan cabang, tetapi pada 4 MSP pertambahan jumlah cabang menunjukkan perbedaan yang nyata. Pemangkasan pada ruas ke-14 menunjukkan pertambahan jumlah cabang yang lebih banyak dibandingkan dengan pemangkasan pada ruas ke-7 maupun tanpa pemangkasan.

Pertumbuhan cabang lateral akibat pemangkasan ini dipengaruhi oleh hormon auksin dan sitokinin yang diproduksi oleh tanaman. Suplai auksin dari tunas apikal tidak terjadi lagi, sehingga kadar auksin dalam ruas di bawahnya berkurang (Takei et al., 2004). Peran auksin menjadi terhenti setelah pemangkasan dan hormon sitokinin berperan penting dalam mengaktifkan pembelahan sel untuk pembentukan cabang lateral (Darmanti dkk., 2008).

Pertambahan Panjang Cabang. Hasil analisis statistik menunjukkan tidak terjadi interaksi antara ketiga kultivar dengan pemangkasan terhadap pertambahan panjang cabang dari tanaman A. arabicum. Pengaruh mandiri perlakuan pada tiga kultivar dengan pemangkasan terhadap pertambahan panjang cabang dapat dilihat pada Tabel 2 .

Perlakuan pada tiga kultivar tidak memberikan pengaruh yang nyata terhadap pertambahan panjang cabang $A$. arabicum. Menurut Arwida (2008), kultivar Yak Saudi dan kultivar Thai Socotranum memiliki karakter pertumbuhan yang lambat. Karakteristik pertumbuhan tersebut tentunya berpengaruh terhadap perlakuan yang diujikan, sehingga belum terlihat perbedaan yang nyata dari tanaman $A$. arabicum hingga umur tanaman 12 MSP.

Perlakuan pemangkasan memberikan pengaruh yang nyata terhadap pertambahan panjang cabang yang dihasilkan. Tanaman yang 
dipangkas pada ruas ke-14 memiliki panjang cabang yang lebih tinggi dibandingkan dengan tanaman yang dipangkas pada ruas ke-7. Hal tersebut diduga karena tanaman yang dipangkas pada ruas ke-14 dari bawah permukaan tanah memiliki batang utama yang lebih tinggi dibandingkan dengan tanaman yang dipangkas pada ruas ke-7 dari bawah permukaan tanah. Batang utama mengandung cadangan makanan, dengan demikian tanaman yang memiliki batang yang lebih tinggi, memiliki cadangan makanan yang lebih banyak pula (Irawati dan Setiari, 2009). Dapat disimpulkan bahwa tanaman yang memiliki batang lebih panjang juga memiliki cadangan makanan yang lebih banyak, sehingga dapat disuplai untuk proses pertumbuhan akan lebih baik.

Tabel 2. Pengaruh Pemangkasan pada Tiga Kultivar terhadap Pertambahan Panjang Cabang Tanaman Kamboja Jepang (A. arabicum).

\begin{tabular}{lllllll}
\hline \hline \multirow{2}{*}{$\begin{array}{c}\text { Perla- } \\
\text { kuan }\end{array}$} & \multicolumn{5}{c}{ Pertambahan Panjang Cabang $(\mathrm{cm})$} \\
\cline { 2 - 7 } $\mathrm{k}_{1}$ & $0,33 \mathrm{a}$ & $0,92 \mathrm{a}$ & $0,94 \mathrm{a}$ & $1,51 \mathrm{a}$ & $1,26 \mathrm{a}$ & $0,95 \mathrm{a}$ \\
$\mathrm{k}_{2}$ & $0,00 \mathrm{a}$ & $0,64 \mathrm{a}$ & $0,51 \mathrm{a}$ & $0,81 \mathrm{a}$ & $0,82 \mathrm{a}$ & $0,71 \mathrm{a}$ \\
$\mathrm{k}_{3}$ & $0,00 \mathrm{a}$ & $0,99 \mathrm{a}$ & $1,08 \mathrm{a}$ & $1,92 \mathrm{a}$ & $1,24 \mathrm{a}$ & $1,14 \mathrm{a}$ \\
\hline $\mathrm{p}_{0}$ & $0,00 \mathrm{a}$ & $0,00 \mathrm{a}$ & $0,00 \mathrm{a}$ & $0,00 \mathrm{a}$ & $0,00 \mathrm{a}$ & $0,00 \mathrm{a}$ \\
$\mathrm{p}_{1}$ & $0,00 \mathrm{a}$ & $0,98 \mathrm{~b}$ & $0,82 \mathrm{ab}$ & $1,51 \mathrm{~b}$ & $1,50 \mathrm{~b}$ & $1,14 \mathrm{~b}$ \\
$\mathrm{p}_{2}$ & $0,33 \mathrm{a}$ & $1,57 \mathrm{~b}$ & $1,72 \mathrm{~b}$ & $2,74 \mathrm{c}$ & $1,82 \mathrm{~b}$ & $1,66 \mathrm{~b}$ \\
\hline
\end{tabular}

Keterangan: Angka yang ditandai dengan huruf berbeda menyatakan berbeda nyata menurut Uji Lanjut Berganda Duncan pada taraf 5\%.

Pertambahan Diameter Bonggol. Hasil analisis statistik menunjukkan adanya interaksi antara perlakuan pada tiga kultivar dengan pemangkasan terhadap pertambahan diameter bonggol dari tanaman A. arabicum pada 6 MSP. Pengaruh interaksi perlakuan pada tiga kultivar dan pemangkasan terhadap pertambahan diameter dapat dilihat pada Tabel 3.

Interaksi antara kultivar Yak Saudi $\left(\mathrm{k}_{1}\right)$ dengan tanpa pemangkasan $\left(\mathrm{p}_{0}\right)$, menunjukkan perbedaan diameter bonggol yang lebih besar dibandingkan dengan perlakuan lainnya. Hal tersebut terjadi karena kultivar Yak Saudi memiliki karakteristik bonggol yang lebih besar dan kokoh, selain itu, tanaman dengan perlakuan tanpa pemangkasan tidak mengalami kehilangan karbohidrat, sehingga karbohidrat dapat digunakan untuk pembesaran bonggol. Penelitian Koentjoro (2012), menunjukkan perlakuan tanpa pemangkasan batang utama menghasilkan diameter batang tanaman melon yang lebih tinggi dibandingkan dengan perlakuan pemangkasan batang utama dan pemangkasan $1 / 2$ bagian batang utama.

Tabel 3. Pengaruh Interaksi pada Tiga Kultivar dan Pemangkasan terhadap Pertambahan Diameter Bonggol Tanaman Kamboja Jepang ( $A$. Arabicum) pada 6 MSP.

\begin{tabular}{cccc}
\hline \hline \multicolumn{4}{c}{ Pertambahan Diameter Bonggol $(\mathrm{mm})$} \\
\hline \multirow{3}{*}{ Kultivar $(\mathrm{K})$} & \multicolumn{3}{c}{ Pemangkasan $(\mathrm{P})$} \\
\cline { 2 - 4 } & Tanpa $\left(\mathrm{p}_{0}\right)$ & $\begin{array}{c}\text { Ruas ke-7 } \\
\left(\mathrm{p}_{1}\right)\end{array}$ & $\begin{array}{c}\text { Ruas ke-14 } \\
\left(\mathrm{p}_{2}\right)\end{array}$ \\
\hline Yak Saudi $\left(\mathrm{k}_{1}\right)$ & $2,89 \mathrm{~b}$ & $0,55 \mathrm{a}$ & $0,63 \mathrm{a}$ \\
& $\mathrm{A}$ & $\mathrm{A}$ & $\mathrm{A}$ \\
RCN $\left(\mathrm{k}_{2}\right)$ & $1,47 \mathrm{a}$ & $0,53 \mathrm{a}$ & $0,53 \mathrm{a}$ \\
& $\mathrm{A}$ & $\mathrm{A}$ & $\mathrm{A}$ \\
Thai Soco $\left(\mathrm{k}_{3}\right)$ & $1,61 \mathrm{a}$ & $0,82 \mathrm{a}$ & $0,90 \mathrm{a}$ \\
& $\mathrm{A}$ & $\mathrm{A}$ & $\mathrm{A}$ \\
\hline
\end{tabular}

Keterangan: Angka yang ditandai dengan huruf berbeda menyatakan berbeda nyata menurut Uji Lanjut Berganda Duncan pada taraf 5\%. Huruf kecil ke arah vertikal dan huruf besar ke arah horizontal.

Berbeda halnya dengan tanaman yang dipangkas, sumber karbohidrat lebih banyak terbuang akibat pemangkasan sehingga bonggol kurang memiliki asupan karbohidrat untuk pembesaran bonggol. Pemangkasan menjadikan laju asimilat pada tanaman terfokus terhadap bagian di atas tanaman, dalam hal ini yaitu pertumbuhan cabang-cabang baru. Hal ini sejalan dengan penelitian Goldsworthy dan Fisher (1996), jumlah asimilat yang mencapai tongkol jagung yang sedang berkembang akan dipengaruhi oleh persaingan internal antara batang, daun, dan tongkol karena setiap perubahan kekuatan satu pengguna akan memengaruhi penyediaan asimilat ke organ lain dan bersaing dengan organ-organ yang sedang tumbuh.

Pertambahan Jumlah Daun. Hasil analisis statistik menunjukkan tidak terjadi interaksi antara tiga kultivar dengan pemangkasan terhadap pertambahan jumlah daun dari tanaman A. arabicum. Pengaruh mandiri perlakuan pada tiga kultivar dan pemangkasan terhadap pertambahan jumlah daun dapat dilihat pada Tabel 4.

Perlakuan pada tiga kultivar tidak menunjukkan pengaruh yang berdeda nyata terhadap pertambahan jumlah daun tanaman A. Arabicum, sedangkan pada pemangkasan memberikan pengaruh yang berbeda nyata. Tanaman yang dipangkas menghasilkan cabang baru yang lebih banyak sehingga jumlah daun yang dihasilkan pun lebih banyak. Sejalan dengan pendapat Yadi 
dkk. (2012), untuk meningkatkan jumlah daun seringkali dilakukan upaya untuk meningkatkan jumlah cabang dari meristem ujung yang muncul dari kuncup dorman pada ketiak daun.

Tabel 4. Pengaruh Pemangkasan pada Tiga Kultivar terhadap Pertambahan Jumlah Daun Tanaman Kamboja Jepang (A. arabicum).

\begin{tabular}{|c|c|c|c|}
\hline \multirow{2}{*}{$\begin{array}{l}\text { Perla } \\
\text { kuan }\end{array}$} & \multicolumn{3}{|c|}{ Pertambahan Jumlah Daun (helai) } \\
\hline & 2 MSP 4 MSP 6 MSP & $8 \mathrm{MSP}$ & 10 MSP 12 MSP \\
\hline $\mathrm{k}_{1}$ & 0,50 a $11,7 a \quad 5,44$ a & $5,44 \mathrm{a}$ & $38 \mathrm{a}$ \\
\hline $\mathrm{k}_{2}$ & 3,05 a $10,0 a \quad 7,44$ a & $5,83 \mathrm{a}$ & 6,33 a 2,66 a \\
\hline $\mathrm{k}_{3}$ & 0,77 a 9,27 a 5,05 a & $5,05 \mathrm{a}$ & 7,11 a 2,55 a \\
\hline $\mathrm{p}_{0}$ & $3,77 b \quad 2,55$ a 2,94 a & $3,88 \mathrm{a}$ & 3,88 a 1,72 a \\
\hline $\mathrm{p}_{1}$ & 0,00 a $13,2 b \quad 6,50 b$ & $5,16 a b$ & 7,22 a $3,50 b$ \\
\hline $\mathrm{p}_{2}$ & 0,55 a $15,2 b \quad 8,50 b$ & $7,27 \mathrm{~b}$ & 5,38 a $3,38 b$ \\
\hline
\end{tabular}

Keterangan: Angka yang ditandai dengan huruf berbeda menyatakan berbeda nyata menurut Uji Lanjut Berganda Duncan pada taraf 5\%.

Pada umur 2 MSP dan seterusnya, hampir setiap minggunya menunjukkan nilai yang lebih tinggi pada perlakuan pemangkasan ruas ke-14 $\left(\mathrm{p}_{2}\right)$ dibandingkan dengan perlakuan pemangkasan ruas ke-7 ( $\left.\mathrm{p}_{1}\right)$ (Gambar 1).

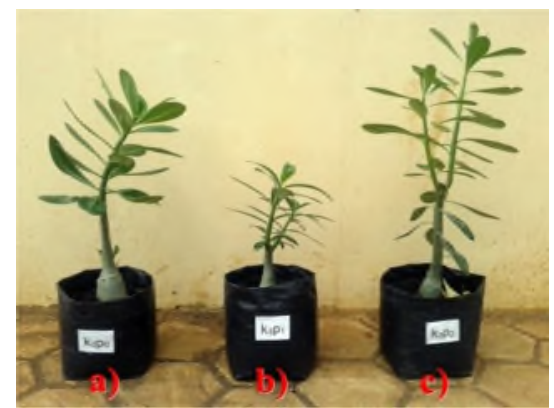

Gambar 1. Perbandingan setiap perlakuan pemangkasan a) Tanpa pemangkasan ( $\left.p_{0}\right)$; b) Pemangkasan ruas ke-7 $\left(\mathrm{p}_{1}\right)$; c) Pemangkasan ruas ke-14 $\left(\mathrm{p}_{2}\right)$

Hal lain juga dapat terjadi bahwa pemangkasan yang lebih tinggi dari permukaan tanah meninggalkan daun yang lebih banyak tidak terpangkas dibandingkan dengan pemangkasan yang lebih rendah. Dapat disimpulkan, bahwa pertambahan jumlah daun ini ditentukan oleh tinggi pangkasan, dimana tinggi pangkasan yang lebih tinggi dari permukaan tanah menghasilkan pertambahan jumlah daun yang lebih banyak.

Luas Daun. Hasil analisis statistik menunjukkan tidak terjadi interaksi antara tiga kultivar dengan pemangkasan terhadap luas daun dari tanaman $A$. arabicum. Pengaruh mandiri perlakuan pada tiga kultivar dengan pemangkasan terhadap luas daun dapat dilihat pada Tabel 5 .
Tabel 5. Pengaruh Pemangkasan pada Tiga Kultivar terhadap Luas Daun Tanaman Kamboja Jepang (A. arabicum) pada Umur 12 MSP.

\begin{tabular}{cc}
\hline \hline Perlakuan & Luas Daun $\left(\mathbf{c m}^{\mathbf{2}}\right)$ \\
\hline $\mathrm{k}_{1}$ & $397,87 \mathrm{a}$ \\
$\mathrm{k}_{2}$ & $378,26 \mathrm{a}$ \\
$\mathrm{k}_{3}$ & $433,33 \mathrm{a}$ \\
\hline $\mathrm{p}_{0}$ & $463,76 \mathrm{~b}$ \\
$\mathrm{p}_{1}$ & $302,38 \mathrm{a}$ \\
$\mathrm{p}_{2}$ & $443,32 \mathrm{~b}$ \\
\hline
\end{tabular}

Keterangan: Angka yang ditandai dengan huruf berbeda menyatakan berbeda nyata menurut Uji Lanjut Berganda Duncan pada taraf 5\%.

Luas daun merupakan tempat berlangsungnya fotosintesis yang akan berpengaruh terhadap fotosintat yang dihasilkan oleh tanaman (Prasetyo, 2004). Pengukuran luas daun juga menjadi hal yang penting dalam analisis pertumbuhan tanaman karena fotosin-tesis biasanya proposional terhadap luas daun. Berdasarkan Tabel 8, dapat dilihat bahwa perlakuan tiga kultivar tidak memberikan pengaruh yang nyata terhadap luas daun dari tanaman A. arabicum.

Menurut Sucipto (2012), ukuran luas daun lebih besar memiliki hasil fotosintesis yang lebih besar pula karena banyaknya stomata yang terdapat pada daun, sehingga pertumbuhan tanaman akan semakin meningkat akibat adanya cadangan energi yang banyak tersedia untuk mendukung pertumbuhannya. Dapat dilihat pada parameter pertumbuhan lainnya, bahwa perlakuan pemangkasan ruas ke-14 $\left(\mathrm{p}_{2}\right)$ lebih menunjukkan perbedaan yang nyata terhadap masing-masing parameter pertumbuhannya. Menurut Permanasari dan Kastono (2012), perlakuan pemangkasan dengan menyisakan 4 daun di atas tongkol menunjukkan luas daun jagung yang lebih tinggi dibandingkan dengan perlakuan pemangkasan bagian tanaman di atas tongkol, kemudian nilai lebih tinggi juga didapat dengan perlakuan tanpa pemangkasan.

Perlakuan $\mathrm{p}_{2}$ dan $\mathrm{p}_{0}$ memberikan pengaruh yang sama terhadap luas daun. Hal tersebut diduga terjadi karena intensitas cahaya di dalam rumah kaca yang kurang, seperti yang telah diketahui, bahwa tanaman A. arabicum lebih optimal tumbuh pada intensitas cahaya yang tinggi, sedangkan di rumah kaca memiliki intensitas cahaya yang cenderung lebih rendah. Selain pengaruh intensitas cahaya, pemangkasan pada ruas ke-14 lebih banyak menyisakan daun yang tidak terpangkas, sehingga total luas daun pada tanaman $\mathrm{p}_{2}$ memberikan pengaruh yang sama dengan tanaman $\mathrm{p}_{0}$. 


\section{Kesimpulan dan Saran}

Berdasarkan hasil dan pembahasan, maka dapat ditarik simpulan dari penelitian yang telah dilakukan, yaitu:

1) Terdapat interaksi antara perlakuan pemangkasan dan tiga kultivar terhadap pertambahan diameter bonggol tanaman $A$. arabicum pada umur 6 MSP. Interaksi yang terjadi, yaitu antara kultivar Yak Saudi dengan perlakuan tanpa pemangkasan.

2) Perlakuan pada tiga kultivar tidak memberikan pengaruh yang berbeda. Pemangkasan pada ruas ke-14 memberikan pengaruh paling baik terhadap pertambahan jumlah cabang, panjang cabang, jumlah daun, dan luas daun pada tanaman $A$. arabicum.

Berdasarkan penelitian yang telah dilakukan, maka dapat diperoleh saran untuk perbaikan penelitian selanjutnya, yaitu perlu dilakukan penelitian lebih lanjut mengenai pemangkasan menggunakan tiga kultivar yang sama dengan waktu percobaan yang lebih panjang.

\section{Ucapan Terima Kasih}

Ucapan terima kasih kami berikan kepada semua pihak yang telah membantu terlaksananya penelitian ini.

\section{Daftar Pustaka}

Ali, AI. 1996. Pengaruh Waktu Pemangkasan Tajuk dan Populasi Tanaman terhadap Hasil Empat Klon Ubi jalar (Ipomoea batatas Lam.). IPB. Tidak Dipublikasi.

Arwida, S. D. 2008. Adenium arabicum Si Bonggol Eksotik. Jakarta: Gramedia Pustaka Utama.

Darmanti, S., N. Setiari., dan T. D. Romawati. 2008. Perlakuan defoliasi untuk meningkatkan pembentukkan dan pertumbuhan cabang lateral jarak pagar (Jatrophacurcas). Jurnal Penelitian. Vol. 16 (2).

Goldswothy, P.R, N., M, Fisher. 1996. Fisiologi tanaman budidaya tropik. Terjemahan
Tohari). GMU Press, Yogyakarta.

Gomez, K. A dan A. A, Gomez. 1995. Prosedur Statistik untuk Penelitian Pertanian. Edisi Kedua. (Diterjemahkan oleh Endang Sjamsuddin dan Yustika S Baharsjah). Jakarta: Universitas Indonesia Press.

Irawati, H dan N. Setiari. 2009.Pertumbuhan tunas lateral tanaman nilam (Pogostemon cablin Benth) setelah dilakukan pemangkasan pucuk pada ruas yang berbeda. Jurnal Penelitian. Vol. 17 (2).

Januwati, M., J. Pitono., dan Ngadimin. 1996. Pengaruh Pemangkasan terhadap Pertumbuhan dan Produksi Terna Tanaman Sambiloto. Prosiding Seminar. Warta Tumbuhan Obat Indonesia. Vol. 3 (1).

Koentjoro, Y. 2012. Efektifitas model pemangkasan dan pemberian pupuk majemuk terhadap tanaman melon (Cucumismelo L.). Berkala Ilmiah Agroteknologi Plumula. Vol 1 No. 1.

Permanasari, I dan D. Kastono. 2012. Pertumbuhan tumpangsari jagung dan kedelai pada perbedaan waktu tanam dan pemangkasan jagung. Jurnal Agroteknologi. Vol. 3 (1) : 13-20.

Prasetyo. 2004. Budidaya kapulaga sebagai tanaman sela pada tegalan sengon. Jurnal Ilmu-ilmu Pertanian.Vol. 6 (1) : 22-31.

Soenanto, H. 2005. Pesona Adenium. Yogyakarta: Kanisius.

Sucipto, 2012. Produktifitas penggunaan lahan dalam teknik pemangkasan tanaman tembakau setelah panen yang ditumpangsarikan dengan kacang tanah. Prosiding Seminar Nasional. Madura: UTM Press.

Suryowinoto, S. M. 1997. Flora Eksotika, Tanaman Hias Berbunga. Kanisius. Yogyakarta.

Takei, K., U. Nanae., A. Koh., K. Takashi., H. Takashi, S. Kazuo., Y. Tomoyuki., and S. Hitoshi. 2004. AtIPT3 is a key determinant of nitrate-dependent cytokinin biosynthesis in arabidopsis. Plant Cell Physiol. Vol. 45 (8) : 1053-1062.

Yadi, S., L. Karimuna, dan L. Sabaruddin. 2012. Pengaruh pemangkasan dan pemberian pupuk organic terhadap produksi tanaman mentimun (Cucumis sativus L.). Jurnal Penelitian Agronomi. Vol. 1 (2) : 107-114. 